\title{
Storying Traditions, Lessons and Lives: Responsible and Grounded Indigenous Storying Ethics and Methods
}

\author{
Doreen E. Martinez
}

\section{check for}

updates

Citation: Martinez, Doreen E.. 2021. Storying Traditions, Lessons and Lives: Responsible and Grounded Indigenous Storying Ethics and Methods. Genealogy 5: 84. https://doi.org/10.3390/ genealogy5040084

Received: 5 June 2021

Accepted: 14 September 2021

Published: 23 September 2021

Publisher's Note: MDPI stays neutral with regard to jurisdictional claims in published maps and institutional affiliations.

Copyright: (C) 2021 by the author. Licensee MDPI, Basel, Switzerland. This article is an open access article distributed under the terms and conditions of the Creative Commons Attribution (CC BY) license (https:// creativecommons.org/licenses/by/ $4.0 /)$.
Department of Ethnic Studies, College of Liberal Arts, Colorado State University, Fort Collins, CO 80523, USA; Doreen.Martinez@colostate.edu

\begin{abstract}
This article offers a conceptual framework on Indigenous storying ethics, storying methods, storying as ruptures and storying interventions, to distinguish elements, premises and practices distinctive to Indigenous storying. This conceptual framework is built from (in)formal relational storying experiences and more structured data from over twenty years of qualitative, ethnographic, and storying projects. In its departure from expected Western methodological approaches to collecting and reporting data, it lives in Indigenous truths and epistemologies in our responsibilities and in our grounding. The interplay between ethics, methods, ruptures and interventions illustrates and centers storying as it speaks of the epistemological power of storying from ancient and traditional nature-based immersions.
\end{abstract}

Keywords: Indigenous; epistemologies; storying; methods; ethics

Thomas King in The Truth about Stories begins:

There is a Story I know. It's about the earth and how it floats in space on the back of a turtle. I've heard the story many times, and each time someone tells the story, it changes. Sometimes the change is simply in the voice of the storyteller. Sometimes the change is in the details. Sometimes in the order of events. Other times it's the dialogue or the response of the audience. But in all the tellings of all the tellers, the world never leaves the turtle's back. And the turtle never swims away. (King 2003, p. 1)

At root to King's offering is an understanding and integration of Indigenous traditions and lessons that demonstrate how our lives are located through values, beliefs and practices. Implicitly our lives are connected and in relationships to our histories and beliefs, through storying and stories as well as tellings and tellers. To recognize this significance, these fundamental renderings, we begin to enter the spaces of an Indigenous consciousness-a consciousness expressed through words, utterances and even silences. For, Indigenous consciousness is an ancient, cultural consciousness (see Brant 1994) that carries forth our interrelated humanity and our planet. The tellings posit the integrity of well-being in Indigenous communities where balance and holism are necessary markers of traditional truths for an array of Native traditions, beliefs and practices. Our tellers illustrate how, "storytelling is a practice in Indigenous cultures that sustains communities, validates experiences and epistemologies, expresses experiences of Indigenous peoples and nurtures relationships and the sharing of knowledge" (Iseke 2013, p. 559). The turtle never leaves, because it is at the core of the story, it is the core belief of time immemorial, of those yet to come, of the relational existence of our traditions, lessons and lives to the land and earth and all beings. We must wonder if the turtle leaves is there a story.? (Intentionally a statement and a question).

Our is used throughout this article to name Indigenous and Native American ways; while variation does exist in our ways, there are thematic and foundational threads from ancient and traditional knowings that are present and practiced today. Our is me. I am an Indigenous woman. I am Mescalero, Apache and for over two and half decades, I have 
been immersed in the study, exploration and experiences of Indigenous epistemologies: how our knowings live, breath, are shared and are created. This purposeful engagement came as a calling to understand medicine references in many situations and by various peoples in the every day, such as medicine as storying, medicine in song, good medicine in laughter and responsibilities and reverence to collective medicine within knowledge and in ceremony. My responsibilities have been my gifts for our collective, all my relations.

The conceptual model offered is necessary to Indigenous storying. Anything otherwise fails our very epistemological practices and in doing so, erases traditions, appropriate reciprocity and reverence and much more. ${ }^{1}$ As noted in the abstract, the interplay between ethics, methods, ruptures and interventions illustrates and centers storying as it speaks of the epistemic power of storying from relational nature-based immersions. Storying must be grounded and pursued responsibly as it is our past, present and future of our very existence. Storying is more than stories or storytelling. It is who, how, when, why and for what, by what. While, storying has become widespread in various situations and for varying needs with a range of successes and also various catastrophes, exploitations and harm(s). Indigenous storying is distinctive, critical, political, beautiful, awe-filled and awe-inspiring, powerful, funny and and (intentional repeat repeat).

\section{Storying Stories: A Brief History}

The practice of Indigenous storying accounts for a "sphere of existence in which people make their lives, individually and collectively, meaningful; and it encompasses both the practices through which meaning is generated and the material forms-dress, food, popular culture, film, art, literature and so forth-in which it is embodied" (Inda and Rosaldo 2002, p. 10; Berkhofer 1978; Churchill 1994; Martinez 2014c, 2016; Segura and De La Torre 1999; Wilmer 1996). Also, it is, as Lewis (Cherokee Nation), in "Art of Storytelling" video highlights, that stories can be of seasons, stories can be specific to tribes or about a message/lesson and/or stories can be one story, one lesson or idea over ten minutes long (Lewis 2021). Storying will exist in many other iterations and purposes. Contemporarily, we witness storying in memes, Indigenous youth rap, electronic music, as well as TikTok videos, documentary films and street art and murals. Indigenous storying is embraced, practiced and comprehended as a sensory system, as in sense modality, integral to epistemological tenants of Indigeneity. The storying connects the heart mind, the head mind, that hears the storm people, the four legged and winged ones, that smells, tastes and knows lessons and living.

Indigeneity demonstrates the critical valuing of Indigenous storying by illustrating, "This common Indigenous worldview and its associated 'deep logic' [which] has an asset base arising out of the intangibles of cultural identity, communal wisdom, values, philosophies and their resulting alternative worldviews" (Harris and Wasilewski 2004, p. 6). This very asset base of intangibles must be used to ground engagement and utilization of Indigenous storying to achieve and appropriately practice the purpose and outcomes of Indigeneity (through storying). In such we (re)claim our protocols, performances, teachings and representations as ours. We (re)cover our lessons and our truth-tellings and that which matters to us. ${ }^{2}$

Said (2005) has further examined and explained the belief and understanding of Indigenous deep logic. He notes the "deep coexistence" (Said 2005, p. 288) of Indigenous societies to relationships, land and beliefs of land and those relationships. I offer that this deep coexistence is then presented in an array of storying. In this article I share a conceptual framework focused on Indigenous storying ethics, storying methods, storying as ruptures and storying interventions, to distinguish elements, premises and practices distinctive to Indigenous storying. This Indigenous storying conceptual framework is built from (in)formal relational storying experiences and more structured data from over twenty years of qualitative, ethnographic and storying projects. In its departure from expected Western methodological approaches to collecting and reporting data, it lives in Indigenous truths and epistemologies. The interplay between ethics, methods, ruptures 
and interventions illustrates and centers storying as it speaks of the epistemological power of storying from relational nature-based immersions.

Prior to our engagement with storying ethics, it is useful to offer a slight more about the use of storying to Indigenous identity and relational practices. Niezen (2003) has discussed how the term 'Indigenous' has moved beyond Western legal or analytical use. Indigenous ${ }^{3}$ is a vibrant expression of identity, which is stated in reverence, worn expressively and vibrantly and reveals the significance and personal connections about each of us collectively. These expressions of identity/identities, badges of prides, revelations and attachments all come to be seen/known through storying from the collective sphere of existence. Further, as early evidence of rupturing and interventional power, it is through these traditional ancient identity practices in which storying unfolds. Thus, "The study of indigenous identity ... invokes people's sense of permanence and their ability to survive and stay close to their cultures and homelands despite almost insurmountable odds" (Niezen 2003, pp. xi-xii), where this sense of permanence and ability to survive is wedded to our deep coexistence, which must be infused with relational deep logic.

Wilson (2008) further exemplifies the relational accountability to all our relations (more-than-human, other humans and place.) He explains that this accountability to the interdependence of the world is sustained through respect, reciprocity and responsibility (Wilson 2008). However, simply returning a report fails to be equitable/reciprocal. Providing a report prior to publishing is a minimum. People need to know what you are saying they said or what you are saying about them. Your reciprocity must be collective rather than didactic (you and I), Christian (give and get), or capitalistic (receive and owe.)

Significantly, this accountability through respect, reciprocity and responsibility returns us to the beauty and awe central to Indigenous consciousness offered by place, more-than-human and other humans. Indeed, "The whakatauki is suggestive, then, of the need for artists, writers, critics and scholars to develop alternative systems for describing how contemporary indigenous arts-in all their evolving, (post)colonial complexity-not only produce various kinds of culturally inflected meaning but also produce various kinds of aesthetic pleasure-'beauty', 'power', and 'excellence'"' (Allen 2006, p. 147). The Māori whakatauki is codified knowledge that depends on language and structure. These offerings (often referenced as types of proverbs) ${ }^{4}$ are "part of a strongly developed Maori oral tradition that convey critical information about aspects of life, society and tribal memory, including ecological knowledge ... many meanings may not be apparent without knowing the historical, cultural and linguistic context from which the whakatauki originated" (Whaanga et al. 2018, p. 1). These iterations and symbols and teachings are expressions, tools and crafts of remembrance, presence, teachings and ways of being; as such, they are implicitly and explicitly beauty and power. And it is these systems of storying that offer truths, ruptures, interventions and beauty, power and awe; and, in such, go beyond notions of myths, individual notes or peculiar realities.

\section{Storying Ethics}

Strikingly, at the end of one of Elan's $\mathrm{s}^{5}$ and my visits (interviews), she asked, "What do you think medicine ${ }^{6}$ is?" I hesitated a little and then replied, "Yeah, it's this way of, I think there's like this richness or this texture to life when you live the medicine way. It's about our connections to our past, to our families and all the critters." Elan said, "Yeah". Then, I added, "I mean that's the best way I can describe it. But, since I'm supposed to be writing about what other people say (I am slightly laughing, more embarrassed then anything), I can't use that. I need to write about what other people say." Elan chuckled somewhat, put her head down, then looked up at me and pronounced, "I think medicine is about the textures and richness of life. It's about connections to our families, all the critters and our past." Then, she summarily proclaimed, "So, ah, you can use my words." We both laughed. Indigenous storying ethics encompass various ways of knowing, how to access that knowing, who owns the tellings, how we present such to others and how we account for our own positions and understandings in these endeavors. "Indigenous [storying] 
approaches seek and understand knowledge within the context of Indigenous worldviews, ontologies and epistemologies" (Johnston et al. 2018a, p. x). Thus, an Indigenous collective epistemological worldview(s) threaded with humor is demonstrated through Elan and my exchange above. We both were engaged in the pursuit of understanding i.e., knowledge and knowledge sharing, and, in our relational capacity, found the expected typified process-I ask and she answers-rather cumbersome and unrealistic.

Even further, an ontological understanding of life being a great mystery ${ }^{7}$ is acted upon through our exchange vs. a particular static definition or concrete singular truth being sought. We offer an example of "Indigenous epistemologies [as] relational and ethical" (Wilson 2008). Wherein, the ethics that are acted upon and integrated are driven from Indigenous values and belief systems. Noticeably, all research protocols and even public storying norms are laden in values and beliefs. Typical Western expectations reinforce individualism and a type of ownership or proprietorship, in which the receiver has ultimate power. Additionally, it is these Western/European/First World ideologies that we must also attend and disrupt. As noted prior, Indigenous research methodologies are born out of/born from Indigenous worldviews (Geniusz 2009; Kovach 2009; Lambert 2014). Additionally, "they are also shaped by centuries of struggle to survive and overcome colonialism" (Johnston et al. 2018b, p. 4), which has been set forth through rules, regulations and expectations of obtaining and gathering stories, as in narratives, as in qualitative research. Therefore, instead, we recognize and pursue:

The observer [the teller] and the observed [the listener] are in the same causal scientific plane ... Neither knowers nor the knowledge they produce are or could be impartial, disinterested, value-neutral, Archimedean. The challenge is to articulate how it is that knowledge [tellings] has a socially situated character denied to it by the conventional view, and to work through the transformations that this conception of knowledge requires of conventional notions such as objectivity, relativism, rationality, and reflexivity. (Harding 1991, p. 12)

Poignantly, in support of collective philosophy and a stark reminder is that "this assertion may seem to be an articulation of a simple truth - one often forgotten because of its simplicity-that when someone who had not spoken at long last speaks, to complete the circuit of dialogue, there must be someone to listen" (Salvo 2020, pp. 7-8). This circle of dialogue reinforces that "Remembrance and resistance are part of that active presence in life" (Breinig 2008, p. 40) of Indigenous traditions and lessons and ontologies and epistemologies. The latter is restated as we seek to substantiate and reiterate key principles and foundations of Indigeneity and Indigenous storying; as it is more than listening. A listener is the conduit of and for our knowings, our traditions, for our responsibilities to the collective and to our very being(s). In this vein, this lifeline, of remembrance and resistance, I recall Jeanne ${ }^{8}$, who said, "Is, not was" when we were talking causally (non-interview moment), visiting and enjoying breakfast at the Nation restaurant. The local news station had just aired a five second clip on Nation land claims. Ours was a brief conversation regarding how Native peoples and cultures are present vs. historical references and framings. The land claims were a relic of the past to the news reporter, barely worth five seconds of news time. I said, "They just don't get it." She replied simply, yet expressively, "Is, not was." ${ }^{9}$ We, then, shifted our conversation naturally to what was going on with other aspects of our lives.

Remembrance as resistance also was present during an Indian Child Welfare Act (ICWA) interview, in which the participant was using Indian sign-language as she retold her early childhood. She had been removed from her family's home as she was labeled a dumb mute. At the 'new school' she was forced repeatedly to stand in the corner for being silent (not speaking). Yet, in her retelling, a resistance to the primitive, uncivilized, unknowing is revealed.

Linda Tuhiwai Smith reminds us, "[I]n these conservative times the role of an Indigenous researcher and indeed of other researchers committed to producing research knowledge that documents injustice, that recovers subjugated knowledges, that helps create spaces for the voices of the silenced to be expressed and 'listened to' and that challenge 
colonialism and oppression is risky business" (Smith 2012, p. 198). Still, researchers are the gatherers (at times) of stories. The ethical obligations we possess then must weave back to our beliefs and our values. Our critical ethics of respect, responsibility and redistribution must be components of the storying capture and at times the storying release. However, we are attuned and hold tight to Indigenous epistemologies and ontologies, for we realize we could seek to "Call that story back... . But, of course, it was too late. For once a story is told, it cannot be called back. Once told, it is loose in the world" (King 2003, p. 10). Therefore, as I have noted prior, it is vital that I position listeners within how Indigenous peoples define and live their lives, which will require fundamental shifts away from binaristic, human-centered, individual gain and profit. Rather, I seek to focus on the awareness, intelligence and astuteness to the daily living of Native/Indigenous/First Nations peoples that has often been denied, ignored or misrepresented, (Martinez 2014b). And, although more spaces of rupture are occurring with increased voices, desires and searches for our voices, we must continue to adhere to Indigenous ontologies and epistemologies. For collectively, I know the tellers and tellings have shaped my understanding of their story(ies) of our traditions, lessons and lives as much as I shape the presentation of their story. Ultimately, "This approach opens up a space for scholars to engage with multiple truths and address question regarding the role(s) of scholarly work in academia and community" (Doerfler 2014, p. 67). When the storying coexists in these multiple truths, we are gifted with the potentialities of "pleasure-'beauty', 'power', and 'excellence'" (Allen 2006, p. 147).

Grounded offerings and responsible considerations for storying ethics:

(1) You must locate storying within place-based understandings and traditions. Know the tellers and tellings of histories and today's needs and living;

(2) Remembrance is resistance. Consider how you change today through retellings of the past;

(3) Reciprocity within collective understandings and principles;

(4) Offerings. Creatively and critically consider how you reinforce respect, collaboration and reciprocity;

(5) Remind yourself of your positionality and intersubjectivity and how it shows up and influences.

\section{Storying Methodologies}

Prior to the actual research visits on medicine, the participants and I talked about my project, my interest and their possible involvement. I believe these early reciprocal relationships, where I would bring food, come to birthday parties, chop wood for ceremony, share my car and much else, in which the project was more tangential to our visits and time together made [research] shifts, reframed the role of the expert and the project outcomes, respecting and reinforcing collective principles. The participants all knew I wanted to hear their perspective of medicine as Indigenous women. I knew most participants at least two years before engaging in any concrete conversation on medicine. They knew I wanted to talk with everyday people instead of expected, celebrated or defined medicine men. They also knew I was going to speak with a range of women varying in age and Nation affiliations. Many of them were eager to participate and read everyone else's stories.

The women demonstrated a desire to help, a desire that was born out of our relationships and the acknowledgment that I was one of them. Beyond a mere blood-as in racial-affiliation, I was one of them because of how I approached the project and how I lived my life. They sought involvement in this particular arrangement and expressed a strong desire to participate, for the combined reasons of the topic, desire to help, my authenticity and the larger potential project outcome. For instance, Carolyn and I had set ourselves up for a visit. As she would say, we got into our chairs, settled in and had our ice tea filled. We had been visiting for a while, talking about family, our lives and generally just telling stories, when she said, "So, Doreen, what's your big question? What is your research question (with a slight humorous mocking tone)?" Similarly, Lorraine commented during the middle of my visit with her, "What's next?" Regina simply asked, "Does this 
help?" while Ricki ${ }^{10}$ said, "I hope that was right". They always helped and, of course, we are always right.

In all visits and chats, there was an informal and interactive atmosphere. Beyond the tape recorder during visits, it would be extremely difficult to surmise there was an interview occurring. We were "visiting". Frequently, the women told stories and I encouraged them by affirming vocally or non-verbally. While I have experienced these checks within other projects, "Storytelling [as] a focus of Indigenous epistemologies, pedagogies and research approaches" (Iseke 2013, p. 559) firmly influenced these medicine engagements and fostered and nurtured our time together.

Soundly, Indigenous epistemologies are practiced through Indigenous storying. The epistemological storying practice elicits, produces and shares knowledge. The sophistication, layering, various considerations and principles are rarely comprehended in depth and breadth, when oft referred to as oral traditions. In that respect, the labeling of oral traditions (by non-Natives) is overly simplistic and serves mainly to differentiate from written expressions. In Kovach's seminal Indigenous methodologies book, she offers:

Indigenous epistemology emphasizes its non-fragmented, holistic nature, focusing on the metaphysical and pragmatic, on language and place, on value and relationships. Within Indigenous discourse, these are aspects of Indigenous epistemologies that consistently emerge. They are all bound by the relational. Relational is not identified as a specific theme because it is wholly integrated with everything else. Indigenous epistemologies live within a relational web and all aspects must be understood from that vantage point. (Kovach 2009, p. 57)

These relational premises infiltrate a tone, tenor and set of obligations to traditions, ways of being and commitments to the land and our futures. Relational extends past and beyond typified notions or relationships, which often depend on personal or familial bonds. Indeed, Wilson points out and reinforces that, "Relational accountability recognizes that interdependence of the world, while also attending to the need to be accountable to the more-than-human, other humans and place in order to sustain it through 'respect, reciprocity, and responsibility'" (Wilson 2008, p. 99).

An example of relational presence in my medicine project was that it was very common for us to be laughing at a story, or even words or sounds used e.g., the use of "ehh". The participants and I shared a lot of "you knows." Most often, either party would respond with "um hum" "yeah", "yeah, yeah", "right" or by various forms of "eh." Rarely was clarification needed. Yet, these "you knows" offered an important site of acknowledgement (of common and akin positionality) since some came as affirmation, some as consensus seeking, some as kinship, some as "that's it" and so forth. You know, this is our journey.

Another way to consider and understand this relational premise comes from James Salvo. He offers, "There's no meaning of being without being-with because there can be no meaning in the presence of only the absolute singular. Communication necessarily requires that there be at least two partaking in the conversation. One must be in communication with someone for there to be meaning, for meaning isn't meaning as such if it isn't at the same time plural" (Salvo 2020, p. 6). I offer his conceptualization to provide the deep logic and coexistence that is permeated within Indigenous storying. Our very being is absent unless it is "with" and with provides meaning. Yet, the quest for meaning must come within known and respected practices. To visit with people on medicine required time, required a presence, connection and showing up; again, it was two years until I began those visits. When it was okay to start these conversations was largely up to the participants instead of university deadlines or others' desires. I was encouraged to just go knock on doors, which of course I had to refuse; plus, I was told to invite myself to consultations between herbalists and patients/clients/friends (Martinez 2008). Being-with must be done in accordance to content, all those involved humans, non-humans and more-than-humans alike.

I view that, "several useful tools to hear or to witness the interrelated relational living histories are to incorporate an understanding of a consciousness of beliefs that are 
we/collective/interrelated" (Martinez 2008, p. 210). This consciousness is infused and foundationally operationalized. One particular technique that could be used was to offer "medicine" examples others stated or that I knew, and ask the women, "What do you think?", "Does that make sense?" or "Have you ever heard that?" This co-production and co-collaboration literally bringing an example from someone else into new visits was familiar and comfortable to all participants—all with permissions. Yet, IRB ${ }^{11}$ processes often fail to support or facilitate co-production or co-collaborations; rather, a very specified list of questions must be approved, and variation or delineation away from them is often deemed unethical. Moreover, when considering the usual required IRB participation letter, be creative and relevant. During a recent community buffalo restoration project, the reverse side of our required IRB letter proudly displayed a buffalo image that was created by a local artist and with permission given to participants that ended up all over town.

Storying is about the collective and in such, the methodological decisions in storying need to honor and replicate practices to support and embrace these relational necessities. Therefore, "This foundational co-producing approach to truth seeking will blur boundaries of expertise and epistemological evidence, and how we pursue justice and of truth itself. We will cross borders of appropriate and necessary practices away from traditional Western, northern, colonialistic models of engagement to those of holistic collective relationships" (Martinez 2014b, p. 17). Additionally, to affirm the need and recognize how Indigenous cultures already perform storying know, "Our interest as researchers is to maximize the wealth of materials that are drawn into the analysis and explanation. It is also our interest to multiply, rather than slim down, the theoretical ideas that we have to work with ... that includes multiplying the local sources of our thinking" (Connell 2007, p. 220). Connell's contemporary theoretical work contributes to the body of Indigenous theory and epistemological work that addresses and actively critiques the critique, dismissal and/or devaluing of relational knowledge practices. Rather, Indigenous storying and epistemological/theory work have broken up the spaces for our ancient consciousness to be heard and understood as necessary inclusions (Martinez 2008, p. 217).

As a type of Indigenous self-reflexivity, it was always necessary for me to ask myself, "what truth do I want to hear?" and "what reality would I be creating?" (Martinez 2014b, p. 4). I recall early on my medicine visits, the answer to what is medicine was "I don't know," "I never thought about how to define it," "You just know it" or such. I thought I was horrible. My first question a failure. I asked myself if I needed to go back and start again. I really thought I blew it, screwed up royally. Then, it hit me. Those are the answers, the truth, and to alter, seek differently or negate would be where I failed. Thus, I kept asking, "What is medicine?" and I kept getting those truths: "hmm, I'm not really sure how to describe it," "Got me," "What's the next question?" I came to truly appreciate the lived expressions and practices of medicine.

Methodologically, I also set up these two guiding questions for this inquiry process: "Why do we care?" and "What does it matter?" (Martinez 2014b, p. 10). I believe they continue to reinforce the relational nature of this project and seek to attend to the listener(s) as well as rupture previous expectations of Indigenous traditions and lives. Why does it matter must be answered from an Indigenous epistemological tenant that our efforts have meaning and purpose to the community. In concert, "Everyone needs to attend to Indigenous inquiry methods not just in the current context of neoliberalism, but always and everywhere because Indigenous inquiry have resisted 500 years of colonization [attempts] and oppression" (Stewart 2018, p. 66).

Grounded offerings and responsible considerations for storying methodologies:

(1) Recognize what truth you are seeking;

(2) Blur boundaries and cross borders;

(3) Incorporate and maximize the relational. We visited vs. interviewed;

(4) Pursue and/or incorporate co-collaborative processes;

(5) Know the reality you are creating. 


\section{Rupturing Storying}

It was late September 2011 and a somewhat typical Colorado day: sunny, dry and rather hot in the direct rays of the sun. The small city I lived in was celebrating Oktoberfest; yeah, slightly earlier. I sat down. There was one other person sitting on the same hay bale at the opposite end wearing a hat, sunglasses and a sweat suit. I said hello. They turned and said hello back. We mutually shared our first names; hers was Jane.

Jane started to share stories about her family and mentioned that her husband had recently passed. She noted that he was one of the last remaining code talkers and asked me if I knew about them. I replied that I did and mentioned my family lineage being Apache and Pennsylvania Dutch. She shared being born on Navajo territory. She is Navajo. ${ }^{12}$ She shared that she went through three different boarding schools and the missionaries were largely responsible for her education. Her parents initially had her and her siblings in school for the opportunities of education. Her emphasis.

She mentioned how some of her strongest memories are of the priest and nuns in the schools. Yet, she strongly recalled the tension of those relationships because of how much they had tried to take away her Indianness. Her emphasis. She shared how they tried to change so much, their dress, their language and the things they valued most like family and spirituality. She strongly recalled the priest calling their ceremonies pagan and against Christianity. She was berated for attending gatherings and speaking proudly of her culture. She would be singled out and attempts to shame her were frequent. She took a deep breath. Then another. After a little time, she paused, then definitively, turned her head directly to me and said, "You know what. ${ }^{13}$ They made me bold and brazen."

The ruptures that occur when bold and brazen are multi-faceted, offering various sites of departure and fractures to the expected and normative historical story. Exquisitely as Jane offers she became bold and brazen at the hands/minds/efforts of the priests and nuns, which breaks away from the typical expectations of priests and nuns as bastions of morality, manners and the civilized. As Clarke and Olesen (1999) claim, we see how "the destabilized methods and disruptive agendas generated here [in theoretical and methodological processes] can be applied in pursuit of the substantive" (p. 355). Indigenous storying provides various means to demonstrate how particular stories produce intercessions and mediations with the substantive, against and to neo/de/colonial impressions, comprehensions and acts. Although particular realizations have emerged regarding boarding schools, there is a substantive rupture against victimry, a rupture to identity (given), a rupture for agency and a rupture regarding Nations.

For ruptures occur when, "Epistemology is concerned with who can be a knower, what can be known, what constitutes knowledge, sources of evidence for constructing knowledge, what constitutes truth, how valid inferences are to be drawn, the role of belief in evidence and related issues" (Gegeo and Watson-Gegeo 2001, p. 57). What is significant in Jane's telling (the knower) is what occurs when storying is capable ethically (what can be known is shared), where truths are the storiers (from a collective belief in evidence) and, with deep breaths (valid inferences), history is ruptured (evidence of knowledge.) Thus, we circle back to Indigenous epistemologies in storying, where the knower and knowings are various and ancient. Wherein the pursuit of knowledge is a responsibility and wherein knowledge must be shared and serve the collective. Indigenous ontological and epistemological storying (Datta 2017) connects to a particular Indigenous relational way of knowing. Knowing comes from context, understandings of significance and importance; knowings from lessons learned and lessons taught; knowings come from evidence from the land and all our relatives; knowings are performed in our dances and songs as well as the bling and murals of today. Truths are from collective beliefs rather than individual interpretations. And, let us also know, that the capture of becoming bold and brazen may invoke a type of celebration, a hooray of sorts; however, there is a toll in Jane's voice, her breath, which offers another layer or rupture.

Additionally, storying ruptures occur, when as noted in recent tribalography scholarship, the focus is on the story, disrupting the space and allowing the story to expand. 
King's (2003) work on the truth about stories highlights how stories can be shortened, lengthened, separated into parts, told to some and not to others. Stories can have pieces added, images and items included, exclamations offered as well as whispers, all of which can rupture previously held images or beliefs. During a visit to Australia, where we were spending time in schools, we were in a primary grade classroom in which the alphabet with "corresponding" images were covering an entire wall. The "I" had a stereotypical image of US plains Natives and it read, "'I' is for Indian's itching." These are why ruptures are necessary, shifting Indigenous people from a prop or object, to full humanity, histories and modern representations.

Also, various Indigenous societies recognize that stories are shared when the story seeks to be told versus the two-leggeds ${ }^{14}$ schedule or agenda. "Tribalography shifts [ruptures] the paradigm in a way that allows for equity and dignity, all the while subverting the conceived notions of history, scholarship, and entrenched narratives" (Francis and Munson 2017, p. 52). In a modern Sami ${ }^{15}$ museum exhibit in Sweden, there are a dozen or so banners with pictures of Sami today and quotes all answering "What does it mean to be Sami?" Several talk about family, traditions, beliefs and foods. One reply: "It means people want to interview you" offering an intimate perspective of the pervasive object of study condition for many Indigenous peoples and ways. Yet, as I read "It means people want to interview you", the other story that emerged was one of insightfulness and humor.

Ruptures also occur when Indigenous consciousness (a marrying of ontologies and epistemologies) is recognized and acknowledged as a consciousness that existed prior to dominant ideologies (Martinez 2016). A fundamental shift of (co)existence begins to emerge and intervene with accounts or premises of human existence past bodily land occupation to lives full of intelligence, traditions and teachings. Critical to this decolonial process is creating, developing and implementing a new epistemic frame (Mignolo 2006) and challenging state citizen/ship and nation expectations and notions. This shift in knowledge and understanding of existence, presence and being is reflected in the naming and claiming of Indigenous storying that must come from belief foundations and offer and serve ancestries, traditions and futures.

In such, the epistemic shift reflects a decoloniality that demands a type of otherthinking that calls for plurality and intercultural dialogue (Mignolo 2006). Storying for evidence and knowledge efficacy needs to move past the quaint and comfortable realms of storytelling for Western or savior pleasure and comfort. Indigeneity, the active vibrant practices of Indigenous epistemologies, presents an intercultural dialogue of sovereignty that can be erased or omitted, which in turn demands these ruptures. Rather, plurality breaks open the multiple locations of knowledge and value of a peoples ${ }^{16}$ resources, limitations, responsiveness and even imperviousness. It introduces stewardship to knowledge and responsibility to the collective versus cultural consumption and colonial citizenship (Martinez 2016).

Robin Wall Kimmerer, in Speaking of Nature (Wall Kimmerer 2017), offers a keystone of epistemic shifts from Indigenous ways of knowing and being. She explains,

Birds, bugs, and berries are spoken of with the same respectful grammar

as humans are, as if we were all members of the same family. Because

we are. There is no ' $i$ ' for nature. Living beings are referred to as subjects,

never as objects, and personhood is extended to all who breathe and

some who don't.

All our relatives is a common Lakota frame further demonstrating a recognition of birds, bugs and berries. It is a story, those three words, all our relatives. And, as Kimmerer provides an example of this epistemic shift, it reveals how the elimination of one word ruptures the dichotomy of human-other, while demonstrating collective values (all our relations) in language use.

We do this work as an incarnation, a personification and embodiment that is offered in the materialization of storying. It is the breath of being. Our storying work requires us 
to move past and disrupt conventional views of Indigenous lives and histories, because "Is not Was" as well as time immemorial, which is another common Indigenous reference to our beginnings. Additionally, another consideration is that while at times we may know us; we engage and produce storying for others.

Grounded offerings and responsible considerations for rupturing storying:

(1) Providing spaces for rupture;

(2) Reframing knowers and knowing;

(3) Hearing the meaning of breath;

(4) Rupturing historical expectations of the marginalized/historically oppressed;

(5) Listening in unexpected spaces and ways.

\section{Storying Interventions}

"My child will have two brains instead of one. One for the Maasai and one for [formal Western] education"17 offered a Maasai mother ${ }^{18}$ (Martinez and Waldron 2006). We ${ }^{19}$ were visiting with her and other Maasai parents and daughters in the homelands, which reside within present-day Kenya. We had visited boarding and day schools, played soccer with the children during recess, saw the children carry wood for that day's lunch cooking needs, laughed, smiled and embraced the many moments of joy given to us. In these spaces absent of electricity and running water, a zeal and dedication for education (knowledge) was prolific.

We visited in fields, waited for mothers to come back from their daily three-mile journey for water and firewood. We chatted in their traditional manyattas often with a small fire going, smoke lightly bellowing and occasionally a chicken or two running about. All in all, what we learned is how needed and important it is for educational systems to provide ways for traditional Maasai knowledge and ways of knowing and more Western science or knowings to coexist, develop and be engaged. Rather than condemning or only offering Indigenous "food, fun and festival" 20 that repeats and perpetuates the romantic and exotic Indigenous peoples and ways, traditional [Indigenous] epistemologies that are knowledge, process and practice must be woven into curriculums. The Maasai ways, their [Indigenous] cosmology, must be brought into the educational and other sites of knowledge production, as part of a vital living history that may indeed question and challenge standards (Martinez and Waldron 2006).

The Maasai illustrated how their (all our) future relies on two (multiple) heads, multiple ways of taking, representing and performing knowings, that will provide the knowledge to negotiate the demands and impact of globalization, climate change and capitalism, while sustaining a vision for the Maasai. This process is about adaptation and a type of hybridization, in which Indigenous societies have long practiced. This adaptability is symbolically heard in the frequent answer, "Because we are here" ${ }^{21}$, to questions regarding our continued existence.

Rupert Costo, a Cahuilla thinker, states, "There is a great and rich store of information still locked in the hearts and minds of Indians all over the nation" (Costo 1964, p. 2). Deloria (1998), over forty years later, continues to concur with these locked hearts and minds and notes that a mere ten percent of Indigenous knowledge is in print, while Fixico reports that while "More than 30,000 manuscripts have been published on American Indians, [however], more than 90 percent of that literature has been written by nonIndians" (Fixico 1996, p. 31). Similarly, Salvo (2020) has further explored this site of necessary intervention, as he notes that Indigenous epistemologies have resisted these positions because they disclose truth. Moreover, as Niezen discusses, there are renewed, growing and ever-present Indigenous interventions occurring to attend, address and elevate Indigenous representations,-yet, distinctively for rights of self-governance and control of land and resources (Niezen 2003). Vividly, "Indigenous research methodologies provide a framework to reconceive of reconciliation" (Ray et al. 2020, p. 12), because it requires relational practices and engagements that demand interventions with and against Western knowledge production. It is these relational expectations to humans, more-than- 
humans and other-than-humans (those that breathe and some that do not) that definitively shapes Indigenous epistemologies. Self-governance is more than control or power in regards to nation-state-nation status. Control of land is more than access and profit of resources. Consider Salvo's relational collective explanation:

We might understand Indigenous epistemologies to be inquiring into knowledge through seeking knowledge specific to the perspective of the conjunction of being-with and being from. If this is so, then we can see how this differs from Western ways of thought that emphasize ideas of authenticity and inauthenticity, ideas that insist upon the autonomy of the self from the collective other, from an individual I from the they. (Salvo 2020, p. 4)

In this piece of Salvo's work, he emphasizes a being-with:-with representing a layering and substance that includes, seeks and embraces sensory systems, beauty, pleasure and awe. I borrow from Wacquant, ${ }^{22}$ a French sociologist, as our interventions seek to multiplicity. He states, "who partakes of the universe that makes him, and that he in turn contributes to making, with every fiber of his body and his heart. Sociology [storying] must endeavor to clasp and restitute this carnal dimension of existence ... to capture and to convey the taste and the ache of action, the sound and fury of the social world" (2004, p. vii). While, there is a dearth of Indigenous knowledge, perspectives and writings, less exists from our perspectives and understandings from our aches, sound and fury that which moves us and why (prior to colonization efforts), which permeate today and include our negotiations of today. This absence furthers our ache and fury.

Let's move to the Zapatistas ${ }^{23}$ intervention. What follows is a storying intervention that provides an individual offering, a collective offering and visual offering. It ruptures expectations of individual storiers or limited expectations of personal/humanized storying. In such, it (re)positions the listeners, recalls the being-with, in which the being expands past a singular criterion, occurrence, or individual, as well as expands the with to include various relational presentations and tellings.

Again, the Zapatistas intervention. Subcomandante Insurgente Moisés (2016) suggests, "Begin to dream and you will see that we can only fight capitalism with good scientific science, the art of the artist, and the guardians of mother nature together with those below from across the world. This is our responsibility." Thus, we are given a call, a charge to intervene on Western science and on capitalism that must be interwoven and reliant with good scientific science, with the art of the artists and with the guardians for nature as our responsibility. Moisés' words were offered at the beginning of the Zapitistas Las ConCiencias, in which the title of the conference brings together the Spanish words for science and awareness (Duncan 2017). The conference designation honed in on its dual purpose. One conference purpose was the Zapatistas commitment to critically explore and name how Western science historically has been an endeavor significantly devoid of consciousness (Meek 2018). Western science has frequently and regularly engaged in practices of people, lands and resources that continues to as well as accelerates the marginalization disproportionately to Indigenous Nations, peoples and lands (including resources). These science projects typically are in service to capital. Secondly, yet more twofold, the conference is a space to explore "the counter-hegemonic potential of science; how can its power be harnessed to identify the cracks in the wall of capitalism, and expand upon them, leading to its dissolution, and the resurgent sovereignty of Indigenous peoples" (Meek 2018). Is, not was.

There is a storying picture at the top Meek's article, Cracks in the Wall of Capitalism: the Zapatistas and the Struggle to Decolonize Science. It is vibrant with conference participants sitting in yellow plastic chairs, the room walls and floor a greenish-blue that is blurred somewhat in the image, the participants dressed in black with color pops of red scarfs and striped textile patterns on their clothes. Each participant has a notebook, some small, and is jotting down information. Each participant in the photo is wearing a black ski-type mask fully covering their heads and necks, leaving only small spaces for their eyes. 
The Zapatistas have declared war against the Mexican government. They are armed and many have died for their cause. They come, though. They come to spaces and conferences for Las ConCiencias, for science and awareness.

A key intervention strategy at the conference(s) ${ }^{24}$ occurs "during the Q\&A and discussion following scientific presentations, Zapatista students engaged in a dialogue with the presenters that provided an opportunity for the scientists to learn from the students' perspectives and knowledge" (Duncan 2017). There is an agency in this practice of knowledge responsibility and engagement, of intervening ruptures of the knowers and knowings, the tellers and tellings. This agency beckons from agency of the natural world (Watts 2013) that Simpson (2017) discusses in her chapter, "Land as Pedagogy", which illustrates the relational braided characteristics and temperament as well as interconnectedness of Indigenous epistemologies. Additionally, we can trace these braids and these connections "to community, ancestral, and sacred sources of knowledge derived from land" (Ray et al. 2020, p. 12). This is how we expose the cracks in the wall and intervene for Indigeneity.

Storying interventions disrupt Western biases imposed upon and frequently utilized to deny, minimize and/or discriminate against Indigenous consciousness and lifeways (Martinez 2012). For our existence happens within a "world of playful cultural hybridity and a social ${ }^{25}$ world of struggle, hatred, winners, and losers that is negotiated by Native peoples" (Deloria 1998, p. 66), in which struggle provides growth and futures, in which losing wins for it sustains life and lands and in which negotiations offer pleasure, beauty and awe. Storying must create spaces to go beyond, to third spaces, to go pre-colonial, pre-history and (pre-)B.C., since time immemorial for generations to come.

Grounded offerings and responsible considerations for storying interventions:

(1) Consider what evidence, data and values you offer in education;

(2) Engage yourself in decolonizing science: in process and outcome;

(3) Remind yourself to capture the "taste and ache of our lives";

(4) Explore and implement truth telling(s);

(5) Locate how interventions impact all.

\section{Storying Echoes: Conclusions}

We speak through a deep coexistence of remembrance and resistance, which echoes through storying. These are our ancestors' echoes, too. Smith, when considering why some Native Americans posed for Edward Curtis, recalls, “On second thought, it's obvious the Indians are resistance fighters pretending to cooperate" (Smith 2009). These are the stories in which we revisit, sing their melodies, rhythms and rhymes. To do so in cadence and tone, we remind ourselves of Indigenous storying ethics and methods that produce our ruptures and interventions, for "The truth about stories is that that's all we are" (King 2003, p. 2). Do consider then: what our storying tells, how, for whom, why and what if they, our storying, is gone or missing or wrong.

Indigenous storying ethics are cradled in Indigenous epistemologies and ontologies, the practice of both being Indigeneity. Wherein, "Indigeneity is, thus, a very ancient global paradigm of sustainability, spiritual interconnectedness and coexistence-of convivencia -of living together" (Harris and Wasilewski 2004, p. 6). For, Indigenous storying comes from relational intimate living with the land, working with land resources to capture and be gifted the diverse learnings there that are fostered over time and place (Battiste 2013) that we offer back, forward and sideways, in the black and white and grays, in and out of the margins. This is our responsibility. Indigenous storying ethics must then be of that same orientation, immersion, experience and purpose.

Indigenous storying methods require a (re)thinking of the knowers and knowings, of the tellers and tellings. Critically, storying methods attend to and check on the truth we seek and the realities our storying creates. We pursue a blurring of boundaries and the crossing of borders to incorporate co-collaborative processes and collective principles. "It [research] aims to provide a demonstration in action of the fruitfulness of an approach that takes seriously, at the theoretical, methodological and rhetorical levels, the fact that the 
social agent is before anything else a being of flesh, nerves, and senses" (Wacquant 2004, p. vii). Moreover, within Indigenous storying, the social agent is the traditions, lessons and lives filled with beauty, help, brazenness, brains and responsibilities. During a recent community engagement project for a buffalo restoration, with the Northern Arapahoe and Eastern Shoshone, ${ }^{26}$ storying provided a means to fulfill our responsibilities and respect with our elders, our buffalo relatives and the lands that will be restored with their presence, because the voices were given space anew.

Indigenous storying is rupturing the valuing of worldviews (education) and innovation (science, technology) in its "deep logic/deep coexistence [that] integrates Indigenous societies, cultures, and peoples [as] societies, cultures, and peoples" (Martinez 2014a). Our worldview "up until now has been undervalued" (Harris and Wasilewski 2004, p. 6). Additionally, by providing rupturing spaces through Indigenous ethics and methodologies, historical and contemporary expectations of the marginalized/oppressed arise. In rupturing the knowing, we hear the sound and fury, breath becomes a story and listening in unexpected spaces and ways becomes inviting, motivating and exciting. We learn, share and know in more diverse ways. Ruptures also become interventions, and interventions will often rupture. Our responsibilities, our basic call, in doing such reaches our highest form of consciousness, the highest form of politics and highest form of spiritual existence and consciousness (Akwesasne Notes 1978, p. 71), wherein the spiritual is the political, the personal, the environmental, the past, present and future and all that swirls around and exists between. Indigenous consciousness knows it is the naturalization of ideological messages of traditions, the lessons we teach and the ways we live. Indigenous storying incorporates, values and acknowledges these positions, knowledges and findings (Martinez 2016, p. 215). Indigenous storying evokes and presents back.

The end of each chapter in King's (2003) The Truth About Stories offers a fitting timbre, an outro to our storying, "Just don't say in the years to come that you would have lived your life differently if only you had heard this story ... You've heard it now".

Funding: The majority of data cited in this article was unfunded. This research with the Maasai was partially funded by a 2005 American Sociological Association: Spivack Community Action Research Initiative.

Institutional Review Board Statement: The study on Indigenous medicine was conducted in accordance with the guidelines, expectations and approved by Syracuse University Institutional Review Board, a Full Board review, in 1999 (https:/ / researchintegrity.syr.edu/human-research/forms/). The Maasai study was conducted in accordance to the expectations and requirements of Christopher Newport University Institutional Review Board and approval in 2004 (https://cnu.edu/ sponsoredprograms/_pdf/cnu-sponsored_programs_handbook.pdf).

Informed Consent Statement: Informed consent was achieved for the study discussing Indigenous medicine in accordance with the guidelines and approved by Syracuse University Institutional Review Board, a Full Board review, in 1999 (https://researchintegrity.syr.edu/human-research/ forms/). Informed consent was achieved for the Maasai study in 2005 by Christopher Newport University expectations and approval through their Institutional Review Board (https://cnu.edu/ sponsoredprograms/_pdf/cnu-sponsored_programs_handbook.pdf).

Data Availability Statement: Not applicable.

Acknowledgments: Thank you Ricki Ginsberg for editing this work. Also, my gratitude to Jamie Haverkamp and Darren Ranco who envisioned this special edition and have been supportive throughout the process, including bringing all edition writers together (virtually) to build community, and exchange ideas and guidance. Lastly to all the participants, co-producers and places these stories have emerged from and asked to be spoken I am grateful.

Conflicts of Interest: The author declares no conflict of interest.

\section{Notes}

1 Various explanations of the 'much more' are offered throughout this article. 
See Heath Justice (2018), Windchief and San Pedro (2019), and Corntassel (2009).

3 Indigenous is title-cased throughout as it is a 'proper noun' identifying Nations, histories and contemporary socio-economic, geographic and political realities, experiences and existences.

4 See Kōrero (n.d.).

$5 \quad$ Elan was raised by her grandmother on Omaha nation territory. They moved to the city of Omaha when Elan was young. Her mother and grandmother are from the Omaha Tribe, and her father is from the Dakota three affiliated (Dakota, Lakota and Nakota Nations). Elan has two daughters and a granddaughter. She liked to shop and is not particularly fond of New York drivers, that being me.

$6 \quad$ I have pursued what medicine means in Indigenous beliefs and practices for over twenty years.

7 The Mescalero Apache believe life is a great mystery. I am Mescalero Apache.

8 Jeanne is Onondaga. She has been doing home births and midwifery for twenty-two years. She told me she's been doing other stuff, too, which is an understatement from my perspective. She is very modest, humble and respectful. We really like telling stories, sitting and just laughing.

9 "Is, not Was" represents an ongoing truth of contemporary Indigenous existence. The news reporter was speaking about us in the past tense. Jeanne corrected him.

10 Lorraine, Regina and Ricki are all Indigenous women who helped in the medicine project.

11 IRB = Institutional Review Board, also called Human Subject Review or Research protocols. These processes usually take the form of an institutional committee, which reviews research projects for ethical standards. They often assess risk-benefit to participants. However, they are highly European/Western in their standards and understandings of knowledge production and community participation.

Navajo was the name given to the Diné. Yet, many Diné use it.

Phrased as a question, that really was a statement by Jane.

Two-leggeds are widely known as human beings in Indigenous spaces. Two-legged schedules would literally be linear, a particular block of time, for certain length of time, etc.

15 The Sami are the Indigenous peoples of today's Scandinavian lands.

16 Peoples is intentionally spelled with a collective pluralization, consciously omitting the apostrophe.

It is important to clarify that the Maasai provided and illustrated a breadth of knowledge and understanding, as in education, in their living.

18 The IRB requirements forced the recognition of the participants as anonymous.

19 "We" includes the project co-PI and co-author, Linda Waldron and I.

A product and by-product of multiculturalism, in which inclusion is entertainment and comfortable. And/or when colonial stories are offered mainly to humanize, at best merely prompting empathy rather than change. See Bishop (1994) and Cai (2002). Four storying words, "Because we are here".

A couple of his specializations are racial inequity and the body.

Zapatista Army of National Liberation (EZLN), an [I]ndigenous armed organization, declared war on the Mexican Government, demanding "work, land, housing, food, health, education, independence, liberty, democracy, justice and peace" (Godelmann 2014).

There have been at least two Las ConCiencias conferences and additional workshops and panels in other settings for this identical purpose. Additionally, see Saldaña-Portillo (2002), and Laako (2015).

I choose to strikethrough social to forgo a potential truncated or false delineation. If read in the spirit of Deloria's offering, this strikethrough does offer particular insight or clarity.

Up on the Wind River Reservation in Wyoming.

\section{References}

Akwesasne Notes. 1978. Basic Call to Consciousness. Summertown: Book Publishing Company.

Allen, Chadwick. 2006. Engaging the politics of pleasures of Indigenous Aesthetics. Western American Literature 41: 146-75. [CrossRef]

Battiste, Marie. 2013. Decolonizing Education: Nourishing the Learning Spirit. Vancouver: UBC Press.

Berkhofer, Robert F., Jr. 1978. The White Man's Indian: Images of the American Indian from Columbus to the Present. New York: Vintage Books.

Bishop, Rudine Sims. 1994. Kaleidoscope: A Multicultural Booklist for Grades K-8. Urbana: National Council of Teachers of English.

Brant, Beth. 1994. Writing as Witness: Essay and Talk. Toronto: Women's Press.

Breinig, Helmbrecht. 2008. Native Survivance in the Americas: Resistance and Remembrance in Narratives by Asturias, Tapahonso, and Vizenor. In Survivance: Narratives of Native Presence. Edited by Gerald Vizenor. Lincoln: University of Nebraska Press, pp. 39-60. 
Cai, Mingshui. 2002. Multicultural Literature for Children and Young Adults: Reflections on Critical Issues. Westport: Greenwood Press. Churchill, Ward. 1994. Indians Are Us? Culture and Genocide in Native North America. Monroe: Common Courage Press.

Clarke, Adele E., and Virginia L. Olesen. 1999. Resisting Closure, Embracing Uncertainties, Creating Agendas. In Revisioning Women, Health, and Healing: Feminist, Cultural, and Technoscience Perspectives. Edited by Adele E. Clarke and Virginia L. Olesen. New York: Routledge, pp. 355-59.

Connell, Raywen. 2007. Southern Theory. Malden: Polity Press.

Corntassel, Jeff. 2009. Indigenous storytelling, truth-telling, and community approaches to Reconciliation. ESC: English Studies in Canada 35: 137-59. [CrossRef]

Costo, Rupert. 1964. Indian Journal to Study History and Development of Native Races. Indian Historian 1: 2.

Datta, Ranjan. 2017. Traditional Storytelling: An Effective Indigenous Research Methodology and Its Implications for Environmental Research. AlterNative: An International Journal of Indigenous Peoples 14: 35-44. [CrossRef]

Deloria, Vine, Jr. 1998. Comfortable Fictions and the Struggle for Turf. In Natives and Academics: Researching and Writing about American Indians. Edited by Devon A. Mihesuah. Lincoln: University of Nebraska Press, pp. 65-83.

Doerfler, Jill. 2014. Making It Work: A Model of Tribalography as Methodology. Studies in American Indian Literatures 26: 65-74. [CrossRef]

Duncan, Sophie. 2017. Zapatistas Reimagine Science as Tool of Resistance. Free Radical. Available online: https://freerads.org/2017/0 4/04/zapatistas-reimagine-science-as-tool-of-resistance/ (accessed on 11 April 2017).

Fixico, Donald L. 1996. Ethics and Responsibilities in Writing American Indian History. American Indian Quarterly, Special Issue: Writing about American Indians 2: 29-39. [CrossRef]

Francis, Lee, and Michael M. Munson. 2017. We Help Each Other Up: Indigenous Scholarship, Survivance, Tribalography, And Sovereign Activism. International Journal of Qualitative Studies in Education 30: 48-57. [CrossRef]

Gegeo, David, and Karen Ann Watson-Gegeo. 2001. 'How We Know': Kwara'ae Rural Villagers Doing Indigenous Epistemology. The Contemporary Pacific 13: 55-88. [CrossRef]

Geniusz, Wendy M. 2009. Our Knowledge Is Not Primitive: Decolonizing Botanical Anishinaabe Teachings. Syracuse: Syracuse University Press.

Godelmann, Iker Reyes. 2014. The Zapatista Movement: The Fight for Indigenous Rights in Mexico. Australian Institute of International Affairs. Available online: https:/ / www.internationalaffairs.org.au/news-item/the-zapatista-movement-the-fight-for-indigenousrights-in-mexico/ (accessed on 11 April 2017).

Harding, Sandra. 1991. Whose Science? Whose Knowledge? Thinking from Women's Lives. Ithaca: Cornell University Press.

Harris, LaDonna, and Jacqueline Wasilewski. 2004. Indigeneity an Alternative Worldview. Systems Research 21: 1-15.

Heath Justice, Daniel. 2018. Why Indigenous Literatures Matter. Waterloo: Wilfrid Laurier University Press.

Inda, Jonathan Xavier, and Renato Rosaldo. 2002. Tracking Global Flows. In The Anthropology of Globalization; a Reader. Edited by Jonathan Xavier Inda and Renato Rosaldo. Oxford: Blackwell Publishing, pp. 3-46.

Iseke, Judy. 2013. Indigenous Storytelling as Research. International Review of Qualitative Research 6: 559-77. [CrossRef]

Johnston, Rochelle, Deborah McGregor, and Jean-Paul Restoule. 2018a. Preface. In Indigenous Research: Theories, Practices, and Relationships. Edited by Deborah McGregor, Jean-Paul Restoule and Rochelle Johnston. Toronto: Canadian Scholars.

Johnston, Rochelle, Deborah McGregor, and Jean-Paul Restoule. 2018b. Introduction. In Indigenous Research: Theories, Practices, and Relationships. Edited by Deborah McGregor, Jean-Paul Restoule and Rochelle Johnston. Toronto: Canadian Scholars, pp. 1-22.

King, Thomas. 2003. The Truth about Stories: A Native Narrative. Minneapolis: University of Minneapolis Press.

Kōrero, Māori. n.d. Whakataukī-Proverbs. Available online: http://www.korero.Maori.nz/forlearners/proverbs.html (accessed on 23 August 2021).

Kovach, Margaret. 2009. Indigenous Methodologies: Characteristics, Conversations, and Contexts. Toronto: University of Toronto Press.

Laako, Hanna. 2015. En las fronteras del Zapatismo con la academia: Lugares de sombra, zonas Incómodas y conquistas inocentes. Prácticas Otras de Conocimientos: Entre crisis Entre Guerras. Mexico: Editorial 2: 223-47. [CrossRef]

Lambert, Lorelei A. 2014. Research for Indigenous Survival: Indigenous Research Methodologies in the Behavioral Sciences. Pablo, MT: Salish Kootenai College Press.

Lewis, Robert. 2021. Art of Storytelling. Smithsonian: The Art of Storytelling-Annual Offerings via National Museum of American Indian. Available online: https: / /www.youtube.com/watch?v=1c5RqUsT4KQ (accessed on 27 February 2021).

Martinez, Doreen E. 2008. Knowingness, Negotiation and Beauty: Recognizing and Sharing Indigenous' Knowledge and Voice. In The Authentic Dissertation: Alternative Ways of Knowing, Research and Representation. Edited by Don Four Arrows Jacobs. London: Routledge, pp. 213-17.

Martinez, Doreen E. 2012. Wrong Directions, New Maps of Authenticity and Indigeneity: Cultural Tourism, Indigenous Commodities and the Intelligence of Participation. American Indian Quarterly 36: 545-73. [CrossRef]

Martinez, Doreen E. 2014a. The Right to Be Free of Fear: Indigeneity and the United Nations. Wicazo Sa Review 29: 2014.

Martinez, Doreen E. 2014b. Methodologies of Social Justice: Indigenous Foundations and Lessons. In Exploring Social Justice: Indigenous Perspectives. Edited by John G. Henson and Alex Wilson. Vernon: JCharlton Publishing, pp. 2-21.

Martinez, Doreen E. 2014c. Polar Bears, Inuit Names and Climate Citizenship: Understanding Climate Change Visual Culture through Green Consumerism, Environmental Philanthropy and Indigeneity. In Culture, Politics and Climate Change: How Information Shapes Our Common Future. Edited by Max Boycoff and Deserai Crow. New York: Routledge, pp. 39-55. 
Martinez, Doreen E. 2016. Holistic Social Justice: Listening to Indigenous Voices and Telling Lessons of Our Traditions, Our Ancestors and Our Futures. In We Still Live Here: First Nations, The Alberta Oil Sands, and Surviving Globalism. Edited by Dr. Michael Hankard. Vernon: JCharlton Publishing, pp. 207-30.

Martinez, Doreen E., and Linda A. Waldron. 2006. My Child Will Have Two Brains, One Maasai, One Educated: Negotiating Traditional Maasai Culture in a Globalized World. Humanity and Society 30: 392-410. [CrossRef]

Meek, David. 2018. Cracks in the Wall of Capitalism: The Zapatistas and the Struggle to Decolonize Science. Toward Freedom. Available online: https:/ / towardfreedom.org/story/archives/americas/cracks-in-the-wall-of-capitalism-the-zapatistas-andthe-struggle-to-decolonize-science/ (accessed on 27 May 2021).

Mignolo, Walter D. 2006. Citizenship, Knowledge, and the Limits of Humanity. American Literary History 18: 312-31. [CrossRef]

Moisés, Subcomandante Insurgente. 2016. Words of the General Command of the Ezln in the Name of the Zapatista Women, Men, Children and Elders at the Opening of the Gathering "The Zapatistas and ConSciences for Humanity. Enlace Zapatista. Available online: http:/ / enlacezapatista.ezln.org.mx/2016/12/27/words-of-the-general-command-of-the-ezln-in-the-name-of-thezapatista-women-men-children-and-elders-at-the-opening-of-the-gathering-the-zapatistas-and-consciences-for-humanity/ (accessed on 27 May 2021).

Niezen, Ronald. 2003. The Origins of Indigenism: Human Rights and the Politics of Identity. Berkeley: University of California Press.

Ray, Lana (Waaskone Giizhigook), Paul N. Cormier, and Leis Desmoulins. 2020. Fish Fry Methodology: A Relational Land-Based Approach to Research and Reconciliation. In New Directions in Theorizing Qualitative Research: Indigenous Research. Edited by Norman K. Denzin and James Salvo. Gorham: Myers Education Press, pp. 9-31.

Said, Edward. 2005. From Oslo to Iraq and the Road Map. New York: Random House.

Saldaña-Portillo, María Josefina. 2002. Reading a Silence: The 'Indian' in the Era of Zapastismo. Nepantla: Views from South 3: 287-314.

Salvo, James. 2020. Introduction: Indigenous Epistemologies as Seeking Knowing Through Being-With and Being From. In New Directions in Theorizing Qualitative Research: Indigenous Research. Edited by Norman K. Denzin and James Salvo. Gorham: Myers Education Press, pp. 1-8.

Segura, Denise A., and Adela De La Torre. 1999. Contradictions of Acculturation and Gender in Latina Health. In Revisioning Women, Health, and Healing: Feminist, Cultural, and Technoscience Perspectives. Edited by Adele E. Clarke and Virginia L. Olesen. New York: Routledge, pp. 155-65.

Simpson, Leanne Betasamosake. 2017. As We Have Always Done: Indigenous Freedom through Radical Resistance. Minneapolis: University of Minnesota Press.

Smith, Paul Chaat. 2009. Everything You Know About Indians Is Wrong. Minneapolis: University of Minnesota Press.

Smith, Linda Tuwahilia. 2012. Decolonizing Methodologies: Research and Indigenous Peoples. London: Zed Books Ltd.

Stewart, Patrick. 2018. Indigenous Qualitative Research in the Neoliberal Public Sphere. In Qualitative Inquiry in the Public Sphere. Edited by Norman K. Denzin and Michael D. Giardina. New York: Routledge.

Wacquant, Loic. 2004. Body E Soul: Notebooks of an Apprentice Boxer. New York: Oxford University Press.

Wall Kimmerer, Robin. 2017. Speaking of Nature: Finding Language that Affirms Our Kinship with the Natural World. In Orion. Northampton: Orion Magazine. Available online: https: / / orionmagazine.org/article/speaking-of-nature/ (accessed on 20 June 2017).

Watts, Vanessa. 2013. Indigenous place-thought and agency amongst humans and non-humans (First Woman and Sky woman go on a European world tour!) Decolonization 2: 20-34. Available online: https://jps.library.utoronto.ca/index.php/des/article/ download/19145/16234/ (accessed on 7 September 2013).

Whaanga, Hēmi, Priscilla Wehi, Murray Cox, Tom Roa, and Ian Kusbas. 2018. Māori oral traditions record an convey indigenous knowledge of marine and freshwater resources. New Zealand Journal of Marine and Freshwater Research 52: 487-96. [CrossRef]

Wilmer, Franke. 1996. Postmodernism and Indigenous World Views. Race, Class and Gender: In the World Cultures an Interdisciplinary and Multicultural Journal 3: 35-58.

Wilson, Shawn. 2008. Research is Ceremony: Indigenous Research Methods. Nova Scotia: Fernwood Press.

Windchief, Sweeny, and Timothy San Pedro, eds. 2019. Applying Indigenous Research Methods: Storying with Peoples and Communities. New York: Routledge. 